\title{
PENGEMBANGAN USAHA UKM BATIK NAGARI TUO PARIANGAN MENGHADAPI TANTANGAN GLOBALISASI
}

\author{
Hamdan Akromullah' ${ }^{1)}$, Hendra'2), Olvianda Ariesta ${ }^{3)}$ \\ 1)23)Program Studi Seni Kriya/ Fakultas Seni Rupa Dan Desain Institut Seni Indonesia Padangpanjang \\ Jl. Bahder Johan Padangpanjang Sumatera Barat/27128

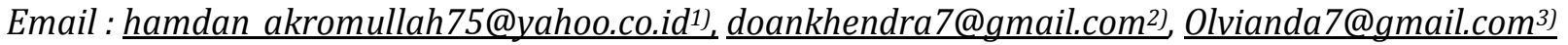

\begin{abstract}
ABSTRAK
Batik Nagari Tuo Pariangan merupakan program revitalisasi kekayaan budaya daerah yang dikembangkan Pemerintah Daerah. Pengembangan batik Pariangan dimulai semenjak ditemukannya naskah kuno pada tahun 2017 di Pariangan yang berisikan motif tradisi dan kandungan sejarah yang sarat dengan pesan dan makna untuk kehidupan masyarakat. Semenjak itu dibentuklah beberapa kelompok pengrajin batik yang salah satunya adalah UKM batik Nagari Tuo Pariangan yang menghasilkan produk batik dengan motif khas Pariangan. UKM batik ini menghasilkan produk batik seperti kain panjang, baju kurung dan selendang yang dijual di rumah salah seorang warga dan menjadi sekretariat UKM batik ini.

Melihat permasalahan diatas, perlu diadakan suatu kegiatan pelatihan kepada pengrajin tentang desain dan pemasaran produk batik. Produk yang dihasilkan kalau dilihat secara desain masih terbatas pada motif tradisi yang ditemukan. Selain itu secara fungsi produk yang dihasilkan masih berupa produk kain panjang, baju kurung dan selendang yang penggunaannya masih terbatas. Oleh karena itu perlu dirancang suatu kegiatan pelatihan dan pembinaan mengenai desain produk dan pemasaran yang nantinya akan mendongkrak popularitas dari batik Nagari Tuo Pariangan. Untuk pemasaran perlu dirancang sistem pemasaran modern dengan membuat galeri khusus untuk mendisplay beragam produk yang dihasilkan. Pemasaran juga perlu didukung dengan sistem pemasaran Online. Hal ini bertujuan untuk memudahkan promosi.
\end{abstract}

Kata kunci: Batik, Desain Produk Dan Pemasaran

\section{PENDAHULUAN}

\subsection{Latar Belakang}

Indonesia memiliki kekayaan budaya lokal yang begitu adiluhung sehingga diakui dunia sebagai budaya khas Indonesia. Salah satu jenis kebudayaan indonesia yang paling fenomenal sehingga diakui oleh dunia adalah Batik. Seni batik Indonesia telah diakui secara resmi oleh UNESCO dengan dimasukkan kedalam daftar representatif sebagai budaya tak benda warisan manusia (Representative list of Intangible Cultural Heritage of Humanity) dalam sidang ke-empat komite antar pemerintah tentang warisan budaya tak benda di Abu Dhabi.( Antara, 2010). Batik secara resmi diakui oleh UNESCO sebagai salah satu kekayaan budaya bangsan Indonesia pada tanggal 2 Oktober 2009. Sejak itu budaya membatik seolah terbangun kembali dengan munculnya beragam kerajinan batik khas daerah yang ada di Indonesia, yang mempopulerkan produk batik dengan motif khas masing masing daerah.

Setiap daerah akan berusaha memunculkan motif khas daerahnya masing-masing yang nantinya akan menghasilkan beragam motif batik khas daerah. Hal ini yang menjadi latar belakang lahirnya kerajinan batik Nagari Tuo Pariangan. Nagari Tuo Pariangan telah ditetapkan sebagai salah satu desa terindah di dunia versi majalah travel budget. Dengan predikat tersebut menjadikan Pariangan sebagai salah satu destinasi wisata budaya yang paling banyak dikunjungi oleh wisatawan yang datang ke Sumatera Barat. Sektor industri pariwisata merupakan sektor yang potensial, untuk dikembangkan sebagai salah satu pengenalan budaya kesenian suatu bangsa (Wahab,1992: 74). 


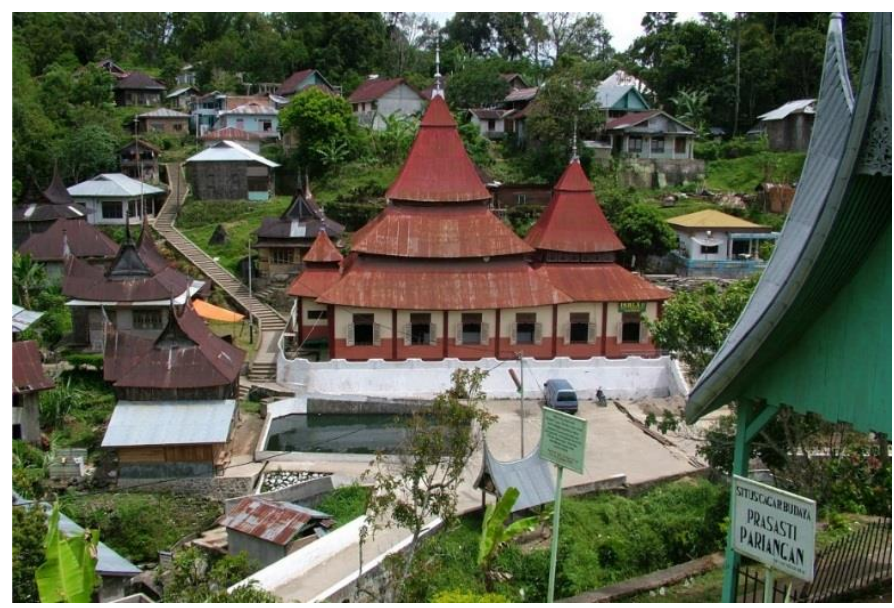

Gambar 1. Nagari Tuo Pariangan

Salah satu pendekatan pengembangan wisata alternatif adalah desa wisata untuk pembangunan pedesaan yang berkelanjutan dalam bidang wisata dan budaya. Keaslian desa wisata dipengaruhi oleh fisik dan sosial desa tersebut seperti ruang, warisan budaya, kegiatan pertanian, bentangan alam, jasa, pariwisata sejarah dan budaya serta pengalaman unik dan eksotik khas daerah. Dengan demikian permodelan desa wisata harus terus dan secara aktif mengembangkan identitas atau ciri khas daerah (Sastrayuda, 2010).Tingginya intensitas wisatawan yang datang mendorong PEMDA untuk mengoptimalkan potensi kekayaan budaya Pariangan yang disajikan kepada pengunjung. Apalagi kekayaan budaya Pariangan tersebut banyak yang belum digali secara maksimal. Salah satu usaha untuk menggali potensi budaya tersebut dengan mengembangkan temuan motif pada naskah kuno Pariangan menjadi motif batik yang nantinya bisa dijadikan batik khas Pariangan. Kerajinan Batik Nagari Tuo Pariangan muncul setelah ditemukannya motif kuno di surau yang ada di Pariangan. Hal itu dikatakan Ketua Dekranasda Tanah Datar Ny. Emi Irdinansyah dalam Focus Group Discussion (FGD) Draf Buku Kerajinan dan Inovasi Iluminasi Naskah Kuno Minangkabau untuk Industri Kreatif yang dilaksanakan Balitbang Provinsi Sumbar di Ballroom Hotel Emersia Batusangkar pada tanggal 22 November 2017. Emi mengatakan bahwa Nagari Tuo Pariangan tidak hanya dikenal sebagai nagari terindah di dunia, namun juga memiliki ratusan aneka motif batik kuno yang terdapat pada Alqur'an koleksi masyarakat setempat yang dinamakan motif kuno Nagari Tuo Pariangan. Ini sangat berpotensi jika dikembangkan menjadi batik yang indah. Motif-motif kuno tersebut sarat makna dan filosofi kehidupan masyarakat Minangkabau zaman dahulu, jadi harus benar-benar dipahami sebelum diaplikasikan kedalam berbagai bentuk kerajinan. (http://kaba12.co.id/2017/11/20/tanah-dataraktualisasikan-motif-kuno-nagari-tuo-pariangan-menjadi-batik/ diposting tanggal 2 Agustus 2018).

Seiring dengan itu pemerintah Kabupaten Tanah Datar telah melaksanakan pelatihan batik kepada tiga kelompok UKM yang bekerjasama dengan ISI Padangpanjang. Pelatihan membatik ini mengangkat motif yang ada di naskah kuno dengan kandungan sastra, sejarah, agama, pengobatan tradisional memiliki ragam Iluminasi (ragam hias) yang tersimpan di surau untuk dikembangkan menjadi motif batik tradisi khas Pariangan. Untuk menghindari plagiarisme, maka motif tersebut dipatenkan sebagai motif khas Pariangan dan dikembangkan menjadi motif batik khas Pariangan. Setelah kegiatan pelatihan selesai hanya tinggal satu UKM saja yang masih aktif sampai sekarang yaitu UKM batik Nagari Tuo Pariangan. Namun eksistensi pengrajinnya masih harus terus diuji dengan beberapa permasalahan. UKM Nagari Tuo Pariangan yang diketuai oleh Zelmawati dan beranggotakan 10 orang tersebut memiliki semangat yang tinggi untuk mengembangkan usaha batik ini. Padahal usaha ini memiliki keterbatasan lokasi usaha yang masih menumpang di sebuah huller (usaha gilingan padi) milik warga. 


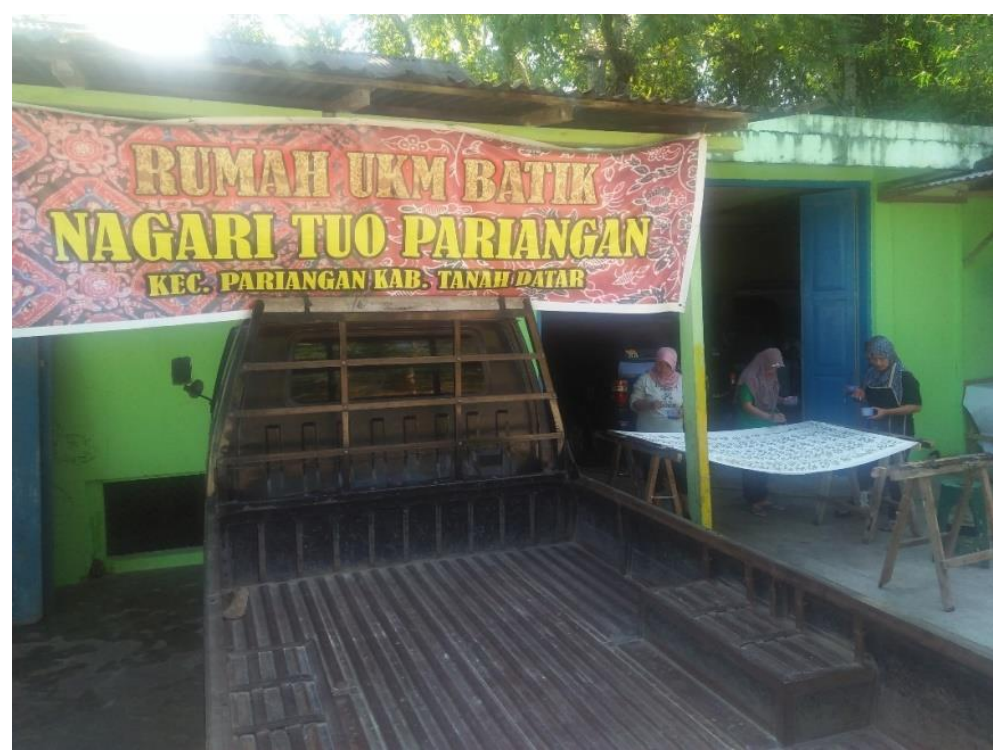

Gambar 2. Situasi unit usaha mitra disudut sebuah huller (penggilingan padi)

Dengan keterbatasan lokasi usaha maka sistem kerja dari usaha ini adalah anggota membuat desain dirumah mereka masing masing, dan ketika mewarnai mereka melakukannya di sekretariat UKM batik. Pewarnaan dilakukan setiap hari sabtu dan minggu sehingga momen ini juga bisa menjadi ajang bagi anggota untuk saling berinteraksi. Setiap anggota memiliki kemapuan yang hampir merata dalam membatik. Anggota unit usaha ini terdiri dari ibu rumah tangga yang memiliki ketertarikan untuk mengembangkan usaha batik ini. Mereka berasal dari warga sekitar Pariangan yang memiliki komitmen yang kuat untuk mengembangkan usaha ini walau dengan segala keterbatasan sarana dan prasarana yang mereka miliki. UKM Batik Pariangan tetap eksis karena memiliki semangat dan keinginan kuat untuk mengembangkan usaha batik yang ada. Saat ini mereka mampu menghasilkan rata rata 10 lembar kain batik per orang yang berarti 100 lembar kain batik per bulannya yang semuanya dipasarkan melalui kantor Wali Nagari.

Masih minimnya pengetahuan dan kemampuan dari pengrajin mengenai teknik membatik dan cara untuk mengembangkan desain batik agar lebih bervariasi menjadi kendala utama pengrajin. Mereka masih terlalu kaku untuk mengembangkan motif batik yang lebih sesuai dengan selera pasar. Masalah kemampuan dalam memadukan warna batik juga belum maksimal dikuasai oleh pengrajin. Selain kurangnya kemampuan dari segi teknis, kendala pemasaran juga menjadi tantangan bagi pengrajin. Mereka masih terbatas melakukan penjualan kepada tamu yang datang ke Nagari Tuo Pariangan. Sedangkan untuk memasarkan secara langsung kepada konsumen, belum bisa dioptimalkan dikarenakan terbatasnya sarana dan strategi pemasaran yang mereka miliki. Seluruh produk yang dihasilkan masih disimpan di kantor Wali Nagari dan jika ada tamu yang datang, maka baru dikeluarkan. Sistem penjualan seperti ini tentu perlu untuk dikembangkan agar produk yang dihasilkan bisa diapresiasi secara maksimal oleh konsumen. Promosi batik tuo Pariangan yang minim membuat banyak wisatawan yang datang tidak mengetahui bahwasanya di Pariangan ada batik khasnya.( Wawancara dengan Wahyudi, 5 Agustus 2018 di Pariangan). Selain itu kurangnya peralatan membatik masih menjadi kendala tersendiri bagi pengrajin. Mereka kurang bisa bekerja dengan maksimal dikarenakan keterbatasan sarana dan prasarana tersebut.

Melihat analisis situasi diatas maka dapat diuraikan beberapa permasalahan yang dihadapi oleh mitra antara lain:

1. Keterbatasan kemampuan dalam pengembangan desain batik sehingga mitra sangat butuh pelatihan pengembangan desain batik untuk menciptakan motif batik kreasi khas Pariangan. Mereka juga menganggap bahwa motif kreasi dengan tema Nagari Pariangan tentunya akan menjadi souvenir yang berkesan bagi wisatawan yang datang. Hal ini merujuk pada banyaknya saran dari konsumen yang menginginkan motif batik yang lebih dinamis dan tidak monoton. Selama ini motif batik yang dibuat hanya berdasarkan pada bentuk motif yang ada pada naskah kuno Nagari Tuyo Pariangan sehingga bentuknya masih kaku. 
2. Keterbatasan kemampuan pengrajin dalam pewarnaan batik sehingga motif batik yang dihasilkan masih cenderung gelap. Dengan peningkatan pengetahuan pengrajin dibidang pewarnaan batik, maka mereka bisa mengkreasikan beragam bentuk dan warna batik yang menarik.

3. Terbatasnya jenis produk batik yang dihasilkan dimana pengrajin hanya membuat batik berupa kain panjang. Mereka belum memiliki wawasan untuk membuat produk lain selain kain panjang. Padahal peluang usaha begitu terbuka lebar jika produk yang dihasilkan lebih beragam dengan tetap mengaju pada motif batik kreasi khas Pariangan. Padahal produk batik tersebut bisa dikembangkan menjadi beragam produk seperti syal, baju kemeja dan juga baju kaos serta celana pendek yang di batik.

4. Keterbatasan pengetahuan pengrajin mengenai sistem pemasaran yang kreatif dan modern padahal Nagari Tuo Pariangan merupakan desa wisata menjadi salah satu destinasi wisata andalan Sumatera Barat. Dalam hal ini perlu diperkenalkan sistem pemasaran yang lebih kreatif dengan memanfaatkan teknologi serta merubah konsep pemasaran yang berorientasi produk pariwisata khas Pariangan.

Dari uraian permasalahan tersebut maka berdasarkan diskusi dengan mitra tentang kendala yang mereka hadapi, perlu dirancang suatu kegiatan pelatihan dengan mitra karena pelatihan pengembangan desain, p-engembangan bentuk produk, peningkatan kemampuan dalam pewarnaan dan pengembangan sistem pemasaran online sangat dibutuhkan oleh pengrajin. Mereka merasa terkendala dengan kurangnya kemampuan yang dimiliki, apalagi potensi dalam pemasaran sangat menjanjikan dikarenakan banyaknya wisatawan yang datang. Namun dikarenakan kurangnya pengetahuan dari pengrajin bagaimana cara pengembangan produk dan pemasaran, maka potensi banyaknya kunjungan wisatawan tersebut belum bisa mereka optimalkan. Mereka sangat mengharapkan dukungan dari pihak ketiga seperti dunia akademisi untuk membuka wacana baru dalam pola fikir dan peningkatan skil yang dimiliki. Hal ini yang menjadi poin penting yaang akan dilaksanakan nantinya dalam kegiatan ini.

\subsection{Metode Pelaksanaan}

Pelaksanaan dari kegiatan pengabdian ini akan dibagi dalam beberapa tahapan antara lain :

1. Presentasi

Kegiatan ini dilakukan untuk menyampaikan garis besar kegiatan pelatihan yang akan dilakukan. Pada saat presentasi ini disampaikan bahwa kegiatan ini merupakan kegiatan berkesinambungan untuk memajukan UKM Batik Pariangan kedepannya. Didalam presentasi nantinya juga ditampilkan beragam bentuk produk batik dari beberapa daerah di Indonesia yang bisa menjadi pedoman bagi pengrajin dalam mengembangkan desain batik Pariaman. Selesai kegiatan presentasi nantinya akan dilanjutkan dengan diskusi mengenai materi yang telah disampaikan. Dalam kegiatan diskusi ini bisa dilihat wawasan dan tingkat pemahaman dari peserta mengenai materi yang disampaikan.

2. Pelatihan desain.

Kegiatan ini bertujuan untuk meningkatkan pemahaman dari pengrajin mengenai hakikat desain dan bagaimana cara pengembangan desain batik itu sendiri. Untuk mengembangkan desain tentunya diperlukan pemahaman mengenai unsur-unsur senirupa dan bagaimana cara mengembangkannya. Kemampuan pengembangan desain ini sangat dibutuhkan pengrajin sehingga mereka bisa berkreasi sendiri untuk menghasilkan desain desain yang menarik dan tidak kaku. Selain itu pemahaman dan pelatihan mengenai pemilihan warna juga perlu ditingkatkan lagi sehingga pengrajin bisa memadupadankan warna pada suatu bidang yang membuat motif menjadi lebih hidup. Desain adalah suatu perwujudan dari suatu gagasan atau hasil karya yang bersifat inovatif dan kreatif dari seseorang atau lebih untuk menciptakan sesuatu pola tertentu dengan cara menentukan serta memperincikan setiap bagian elemen atau komponen dari pola tersebut serta antara hubungannya satu dengan yang lain, sehingga tersusun suatu pola dari bentuk yang merupakan suatu keseluruhan. (Prawira, 1983:1).Kegiatan pelatihan ini juga mencakup bagaimana mengembangkan fungsi dan bentuk dari produk batik tersebut. Produk batik yang dihasilkan bisa menjadi beragam bentuk dengan desain dan penempatan motif yang menarik sesuai dengan bidangnya. Pemahaman bentuk dan proporsional desain ini akan menjadi pengalaman yang berharga bagi pengrajin sehingga mereka bisa berkreasi kedepannya. Kegiatan merupakan upaya untuk menarik minat wisatawan yang datang, sehingga walaupun produk batik Pariangan ini baru dikembangkan, namun konsumen tetap merasa puas dan tertarik dengan keragaman desain bentuk dan motif yang hadir. Pelatihan ini menggunakan media 
kertas dan kemudian diberikan kesempatan kepada peserta untuk menyempurnakan atau mengembangkannya menjadi desain yang lebih kreatif. Setelah beberapa desain dikumpulkan, selanjutnya akan dilaksanakan kegiatan penyempurnaan desain itu dan penyesuaiannya dengan bidang yang akan ditempatkan. Penempatan desain pada bidang kain nantinya juga mempertimbangkan makna filosofi dari motif yang akan diterapkan.

3. Pengembangan jenis produk yang dihasilkan

Produk batik yang selama ini dihasilkan oleh pengrajin adalan kain panjang. Padahal beragam jenis produk bisa dihasilkan dan menjadi souvenir khas yang menjadi andalan Pariangan. Dengan memberikan pelatihan mengenai cara menghasilkan beragam produk batik seperti kemeja batik, syal batik, dan baju kaos batik yang semuanya dihiasi dengan motif batik khas Pariangan, maka omzet penjualan pengrajin bisa meningkat, dan juga wisatawan yang datang juga memiliki beragam pilihan produk batik yang menarik.

4. Pemasaran produk

Salah satu kendala utama yang dihadapi oleh pengrajin adalah bagaimana cara memasarkan produk yang telah selesai dibuatnya. Produk yang telah dibuat tentunya siap dipasarkan. Untuk pemasaran selama ini masih mengandalkan wisatawan yang datang dan tamu yang datang melalui Kantor Wali Nagari. Ketika tamu datang, maka mereka akan diperlihatkan produk batik yang telah dihasilkan yang disimpan didalam lemari di kantor Wali Nagari tersebut. Hal ini dikarenakan belum adanya tempat yang memadai untuk memajang produk yang dihasilkan. Keterbatasan ini perlu diperjuangkan sehingga ketika konsumen datang, mereka juga merasa puas dan bisa mengapresiasi secara maksimal. Padahal pemasaran dan bagaimana cara kita memajang produk untuk dijual adalah hal yang krusial. Pembeli akan merasa puas dengan produk yang dibelinya jika produk tersebut dipajang dengan baik dan mereka akan memiliki kepuasan batin ketika membeli. Hal ini yang perlu disiasati sehingga ketika konsumen datang mereka datang dan memiliki kesempatan untuk mengapresiasi beragam produk yang dihasilkan.

Untuk mendukung pemasaran tersebut juga dirancang sebuah website UKM Nagari Tuo Pariangan yang nantinya akan membantu memasarkan produk yang dijual. Di situs tersebut, konsumen bisa melihat profil UKM, sejarah berdirinya dan beragam produk yang dihasilkan. Selain itu mereka juga ditawarkan harga yang bersaing dan kompetitif sehingga lebih diapresiasi pengunjung. Bahkan disitus ini mereka juga bisa melakukan pembelian online diamanpun berada. Dengan sistem penjualan modern seperti ini, konsumen akan memiliki kesempatan memiliki produk batik Pariangan dimanapun mereka berada.

\section{HASIL DAN PEMBAHASAN}

Kegiatan pengabdian masyarakat ini ditujukan untuk lebih meningkatkan kemampuan pengrajin dalam mengembangkan UKM Batik Pariangan. Untuk pelaksanaan kegiatan pelatihan ini dijadwalkan dilaksanakan dalam sepuluh (10) kali pertemuan sehingga tujuan dari kegiatan bisa terlaksana dengan baik. Untuk menyukseskan pelaksanaan kegiatan pelatihan ini, maka dirancang beberapa tahapan untuk memudahkan penyampaian materi sehingga bisa diterima oleh peserta. Secara garis besar langkah tersebut antara lain (1) Koordinasi, (2) pelaksanaan dan (3) evaluasi. Langkah koordinasi yang dimaksud adalah penyampaian rencana kegiatan ini oleh ketua tim pengabdi ke guru di SD dan SMP yang ada. Dalam koordinasi ini diadakan diskusi singkat mengenai rencana kegiatan dan juga hasil yang ingin dicapai nantinya. Dalam kegiatan ini juga diadakan diskusi dan saling dengar pendapat antara tim dan guru mengenai startegi pelaksanaan kegiatan ini nantinya.

\subsection{Pelaksanaan kegiatan}

Pelaksanaan kegiatan dimulai dengan kegiatan presentasi mengenai pentingnya untuk mengembangkan usaha batik Nagari Tuo Pariangan ini. Hal tersebut untuk menumbuhkan kesadaran dari pengrajin bahwa untuk mengembangkan usaha batik Pariangan ini, bukan hanya sekedar dengan menghasilkan produk batik saja, namun juga perlu dengan pengembangan desain produk batik, variasi produk batik dan juga strategi pemasaran yang tepat. Hal ini bertujuan untuk meningkatkan omset dari pengrajin itu sendiri. Kegiatan pelatihan ini dimulai dengan presentasi mengenai target pelaksanaan kegiatan pengabdian ini. Para pengrajin diberikan materi mengenai potensi pariwisata Pariangan yang harus dioptimalkan oleh pengrajin. Dengan banyaknya wisatawan yang datang dan 
berkunjung ke Pariangan, maka pengrajin dituntut untuk menghasilkan beragam produk cendramata yang menjadi oleh-oleh untuk wisatawan yang datang. Sebagai pengrajin batik khas Pariangan, maka pengrajin dituntut untuk mengembangkan produk batik yang dihasilkan menjadi beberapa produk cenderamata.

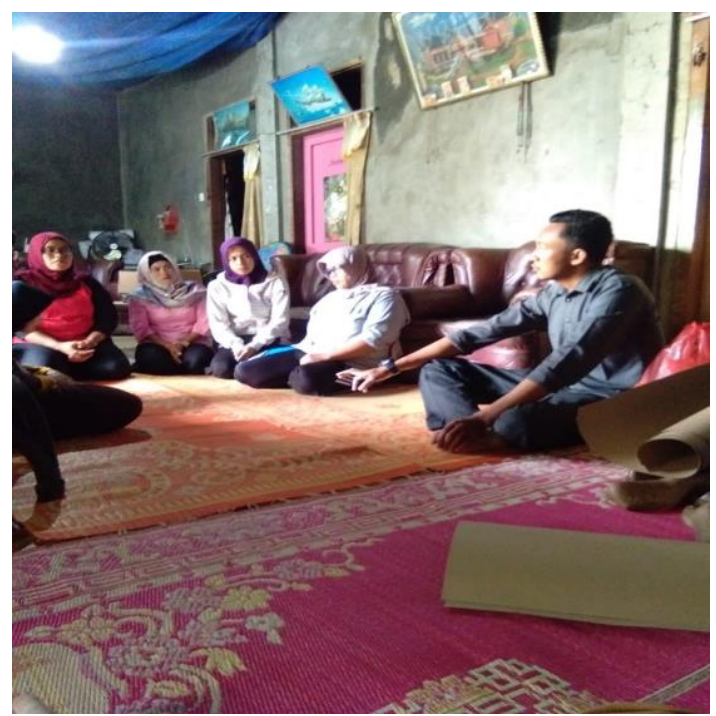

Gambar 2. Presentasi dan diskusi dengan pengrajin

Beberapa produk cendramata yang sangat berpotensi untuk di jual antara lain baju kaos batik khas Pariangan, sandal dan sepatu batik, sajadah batik, kotak tisu batik dan syal batik. Produk tersebut bisa dijadikan cendramata bagi wisatawan yang berkunjung ke Pariangan. Selanjutnya pengrajin juga diarahkan untuk mengembangkan sistem pemasaran produk dari sistem tradisional ke pemasaran modern dengan memanfaatkan jaringan internet.

Setelah presentasi dilaksanakan, maka dilanjutkan dengan sesi tanya jawab mengenai materi presentasi yang disampaikan. Selain itu juga dilakukan diskusi untuk menampung beragam ide dari pengrajin serta beragam permasalahan yang mereka hadapi selama ini. Setelah kegiatan presentasi dan diskusi dilanjutkan dengan pelatihan desain motif batik khas pariangan. Dalam kegiatan ini peserta diberi pengarahan cara mengembangkan motif batik khas pariangan. Pengembangan desain meliputi kreasi motif, pola sebaran motif dan pengetahuan cara menerapkan motif pada bidang kerja. Selama kegiatan ini peserta diberi pemahaman bagaimana cara menerapkan motif tersebut pada bidang kerja yang akan dibuat nantinya, karena setiap bidang kerja akan memiliki perbedaan dalam penerapan motifnya.

Setelah peserta memahami bagaimana cara pengembangan motif, dilanjutkan dengan pelatihan pembuatan baju kaos batik. Pembuatan baju kaos batik merupakan salah satu produk yang cukup strategis dalam upaya meningkatkan pendapatan pengrajin gerabah. Hal ini dikarenakan baju kaos dengan motif batik masih sangat langka diproduksi di Sumatera Barat. Padahal baju kaos dengan motif batik merupakan salah satu souvenir yang paling laris dan biasanya diincar oleh wisatawan yang datang ke suatu objek wisata. Hal ini dikarenakan baju kaos batik bisa dibeli dengan harga terjangkau dan biasanya motif batik yang dihasilkan memiliki karakter khas daerah tersebut. Baju kaos dengan motif batik tersebut biasanya lebih diminati karena bisa dipakai oleh konsumen dari berbagai kalangan. Pembuatan baju kaos batik dimulai dengan membuat desain motif batik terlebih dahulu yang selanjutnya motif yang telah dibuat tersebut dipindahkan ke baju kaos yang akan di batik. Pola penyebaran motif dan komposisi motif tentunya menjadi perhatian yang disesuaikan dengan bidang bajunya. Setelah motif batik diterapkan ke baju kaos, dilanjutkan dengan mencanting sesuai dengan pola yang sudah di buat. 

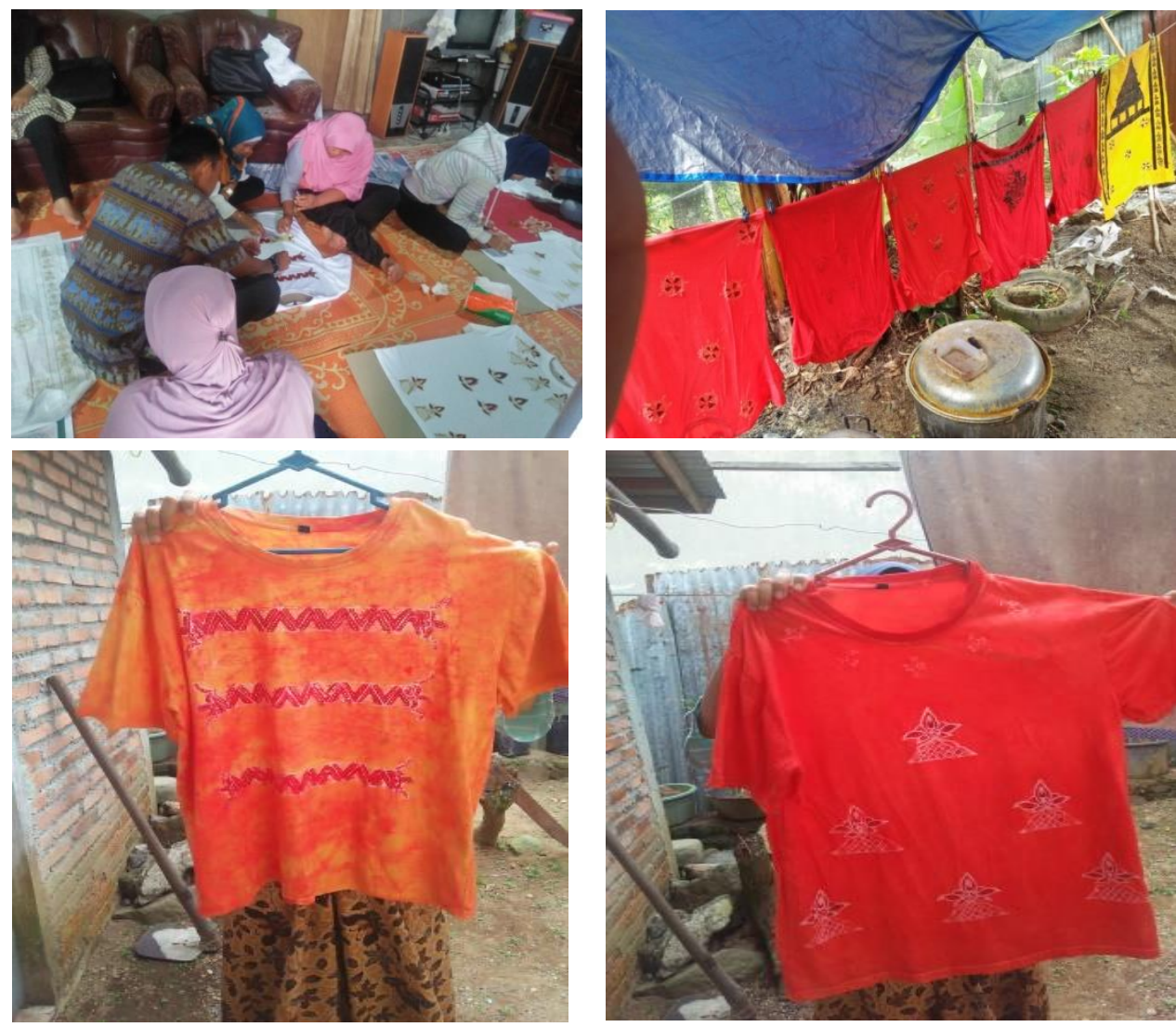

Gambar 3. Proses pembuatan baju kaos batik

Proses pencantingan menggunakan canting dan lilin (malam) yang dipanaskan dengan kompor batik. Setelah proses pencantingan selesai, maka dilanjutkan dengan proses pemberian warna dasar untuk baju kaos. Salah satu warna dasar yang dipilih adalah warna kuning. Setelah pewarnaan dasar selesai, pakaian di angin-anginkan kemudian dilanjutkan dengan proses penembokan yaitu menguaskan lilin parafin yang telah dipanaskan ke seluruh pemukaan kaos yang telah diwarnai. Penguasan dilakukan secara cepat agar lilin parafin dapat menyebar secara merata. Selanjutnya setelah di lapisi dengan lilin parafin, ditunggu sampai lilin kering dan kemudian baju di remukkan untuk membentuk efek pecah pada lilin tersebut. Efek remuk tersebut akan menjadi pola pada baju nantinya. Setelah itu baju kembali di warnai dengan warna merah sehingga efek remuk/pecah tersebut berwarna merah. Setelah diwarnai dengan warna merah baju diangin-anginkan dan setelah kering akan terlihat perpaduan warna kuning dan merah sebagai warna motif tersebut.Kegiatan pembuatan baju kaos batik tersebut berlangsung selama empat hari pertemuan dan di akhir kegiatan dilanjutkan dengan evaluasi.

Kegiatan selanjutnya adalah pembuatan sandal dan sepatu batik. Dalam kegiatan ini pengrajin dibimbing bagaimana cara membuat sandal santai dengan memanfaatkan perca kain batik sebagai dekorasinya. Selain sandal batik, pengrajin juga dilatih untuk membuat sepatu yang divariasikan dengan kain batik. Pembuatan sandal batik menggunakan busa yang dijadikan sebagai alas kaki. Langkah pembuatan sandal adalah dengan membuat pola terlebih dahulu diatas permukaan karton jerami dengan menggunakan mal yang terbuat dari kayu. Mal pembuatan sepatu yang digunakan memiliki beragam variasi ukuran dari nomor 37 sampai dengan 42. Ukuran tersebut juga dibedakan antara pria dan wanita. Setelah pola terbentuk dikarton kemudian pola tersebut dipindahkan ke permukaan busa/ foam putih yang memiliki ketebalan $4 \mathrm{~mm}$. Setelah itu maka busa tersebut digunting dengan pola yang ada untuk kemudian siap menjadi alas kaki. Kemudian pola yang sama juga dibuat pada busa dengan ketebalan $2 \mathrm{~mm}$. Busa ini berfungsi sebagai lapisan atas dari sandal tersebut. Setelah pembuatan alas selesai dilanjutkan dengan membuat jepitan sandal yang dibuat dari busa. Ukuran jepitan sandal tersebut dibuat dengan berpedoman pada mal sandal yang digunakan untuk menentukan berapa tinggi jepitan sandal tersebut. Jepitan sandal ini kemudian diberi variasi dengan menggunakan kain batik yang dilemkan sehingga menjadi lebih menarik. 

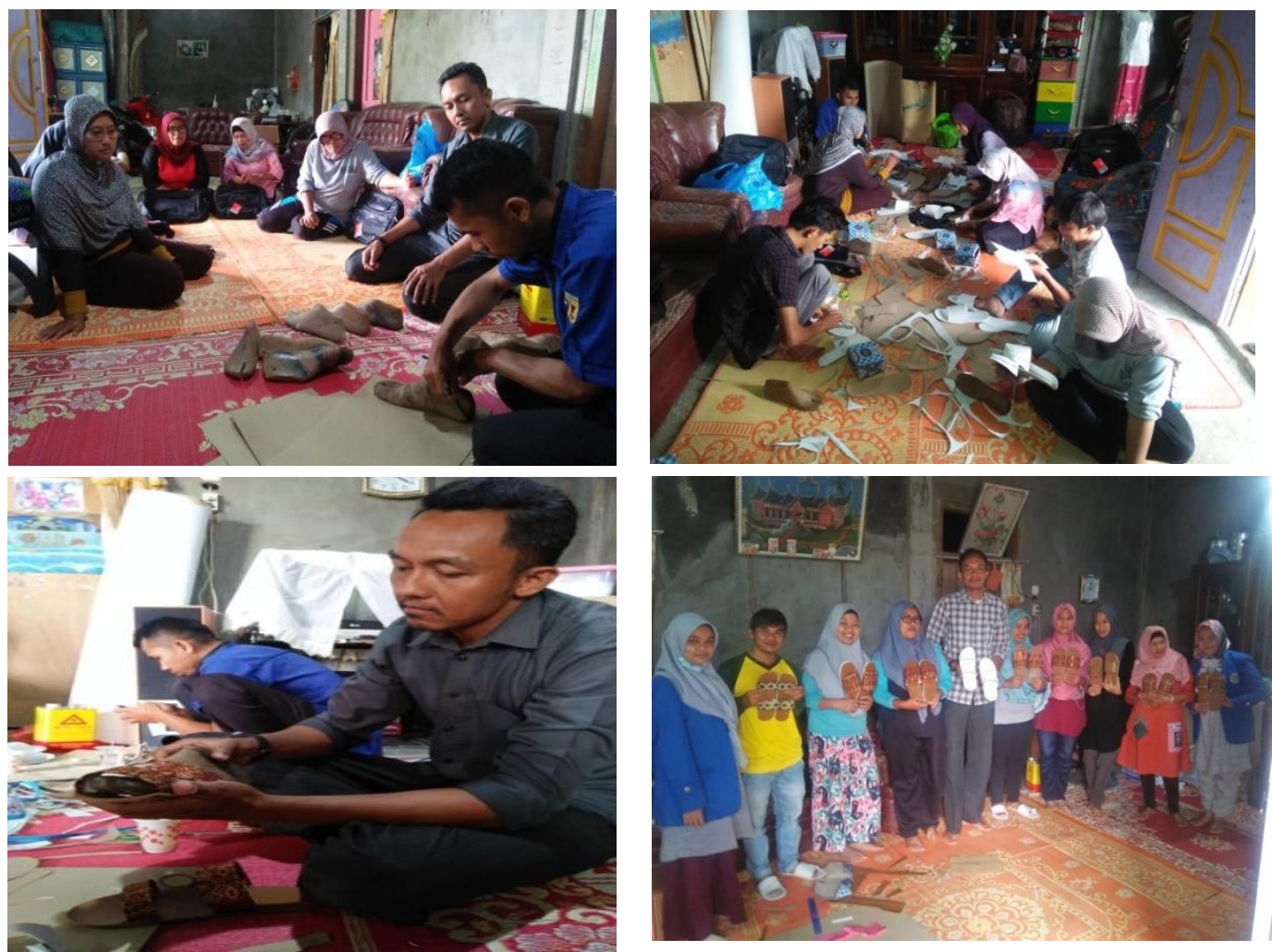

Gambar 4. Kegiatan pembuatan sandal batik

Setelah membuat sandal batik, maka dilanjutkan dengan membuat kotak tisu dari sisa perca batik. Proses pembuatan kotak tisu tersebut dimulai dengan membuat model kotak tisu tersebut dari karton jerami. Karton tersebut dibuat menjadi beberapa tipe dan model kotak tisu yang nantinya akan memiliki tutup yang dapat dibuka. Karton yang sudah dibuat modelnya digunting dan kemudian dilipat sesuai pola. Selanjutnya karton tersebut dilapisi dengan kain batik. Proses melapisi dengan kain batik ini harus memperhatikan bagaimana pola dari motif batik tersebut dan bidang penempatannya. Proses penempelan batik adalah dengan di lemkan menggunakan lem cap kambing. Setelah di lemkan, kemudian diberi lapisan untuk bagian dalam kotak yang bertujuan untuk menutupi permukaan kotak bagian dalam. Setelah seluruh permukaan tertutupi, maka kotak tisu sudah siap untuk digunakan dengan memasukkan tisu yang sesuai dengan ukurannya.

Setelah pemanfaatan kain perca batik, maka selanjutnya adalah pengembangan produk batik pariangan. Produk UKM batik Pariangan selama ini adalah berupa kain panjang. Padahal banyak jenis produk yang bisa dihasilkan dari kain batik tersebut. Salah satunya adalah membuat sajadah batik. Sajadah batik ini bisa dihasilkan dari kain panjang tersebut. Satu buah kain panjang bisa menghasilkan empat buah sajadah batik. Sajadah batik yang dibuat ini dengan memanfaatkan kain batik yang ada namun dengan motif yang lebih spesifik ke bentuk sajadah itu sendiri. Motif yang menjadi andalan adalah bentuk dari Masjid Tuo Pariangan. Bentuk Masjid tersebut memiliki karakter yang menarik akan menjadi motif utama pada bagian tempat sujudnya. Selanjutnya untuk bagian motif pendukung, bisa divariasikan dari pengembangan motif batik khas Pariangan yang ada. Ukuran sajadah batik yang dibuat berkisar antara $70 \mathrm{~cm} \times 150 \mathrm{~cm}$. Dengan pengembangan jenis produk tersebut, maka akan memberikan banyak pilihan bagi wisatawan yang datang. Sajadah batik ini dibuat dengan proses yang sama dengan membuat produk batik biasa. Jadi kain batik diukur sesuai dengan polanya kemudian dilanjutkan untuk membuat motif sesuai dengan fungsinya yaitu sajadah. Kain sajadah ini nantinya akan dijahit dengan polanya dan nantinya akan disesuaikan dengan bentuk sajadah tersebut. Setelah dijahit keseluruhannya maka kain sajadah ini siap untuk dipasarkan.

Selain kain sajadah, produk pengembangan dari batik Pariangan ini adalah syal batik. Produk ini dibuat dengan ukuran $50 \mathrm{~cm}$ x $160 \mathrm{~cm}$. Produk syal tersebut dibuat dengan proses yang sama dengan membatik biasa, namun yang berbeda adalah bagaimana cara menempatkan dan komposisi motif yang dihasilkannya. Syal ini nantinya akan diberi jambul pada bagian ujungnya sehingga akan menjadi lebih 
menarik lagi. Pembuatan syal ini tentunya bisa menjadi pilihan bagi wisatwan yang datang karena memiliki harga yang lebih terjangkau. Setelah kegiatan pengembangan produk selesai dilaksanakan, maka dilanjutkan dengan pelatihan pemasaran produk secara online. Dalam kegiatan ini para pengrajin diberi pengarahan mengenai cara memasarkan produk secara online sehingga dapat dikenal oleh masyarakat. Pengembangan metode pemasaran ini tentunya juga akan meningkatkan angka penjualan produk karena konsumen bisa memesan produk kapanpun dan dimana saja.
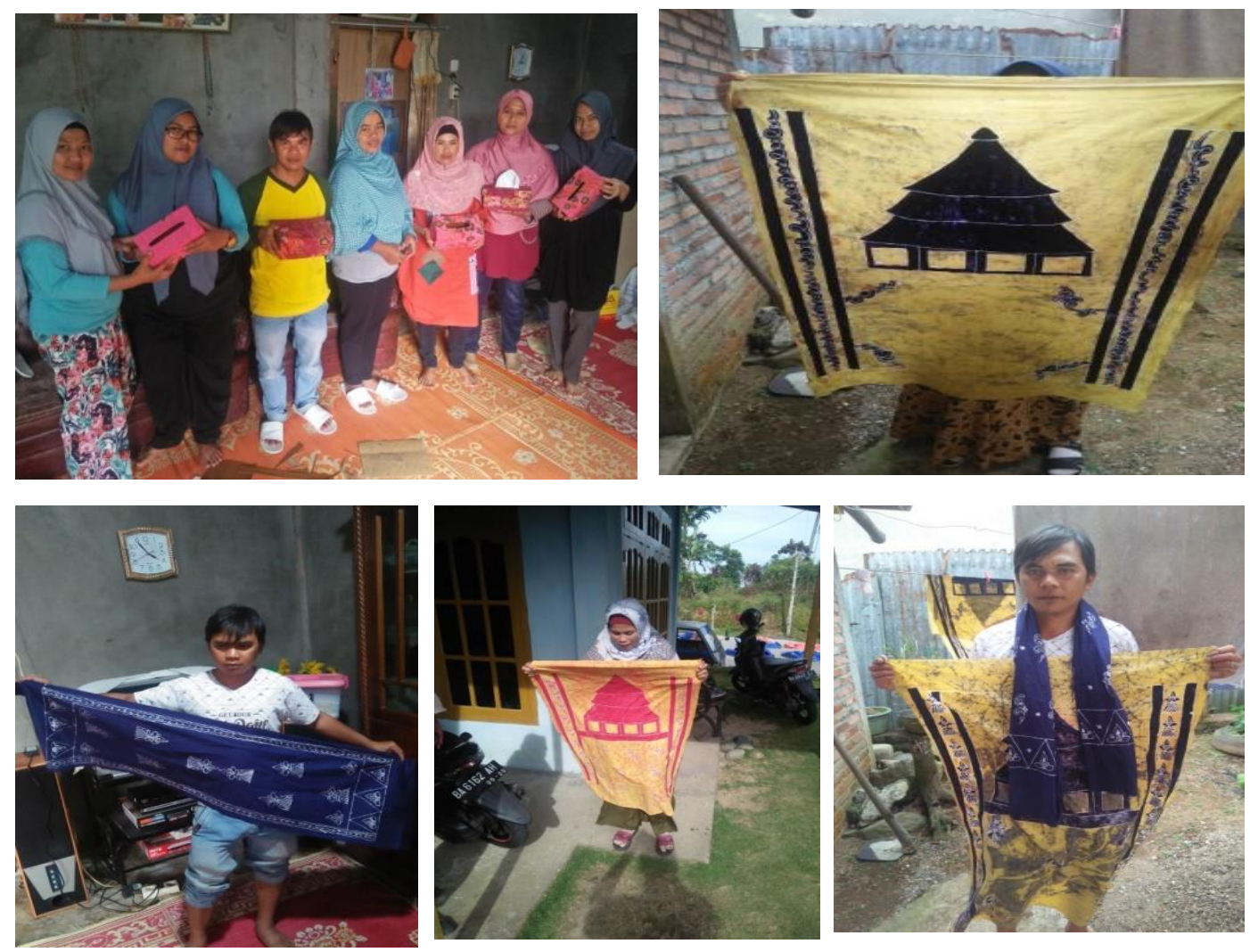

Gambar 6. Beberapa jenis produk yang dihasilkan oleh pengrajin sepertikotak tisu, syal batik dan sajadah batik

Dengan terlaksananya kegiatan ini, maka diharapkan akan meningkatkan pendapatan dari pengrajin UKM batik Pariangan. Dengan beragam produk yang dihasilkan tentunya wisatawan yang datang memiliki beragam pilihan dalam menentukan produk yang akan dijadikan souvenir. Selain itu produk yang diinginkan juga bisa didapatkan secara online bagi wisatawan yang belum sempat membeli secara langsung.

\section{KESIMPULAN}

Kegiatan pelatihan desain gerabah ini merupakan salah satu kegiatan yang berguna untuk mengembangkan usaha batik di Nagari Tuo Pariangan. Kegiatan ini sangat mendesak dilaksanakan dikarenakan status Nagari Tuo Pariangan sebagai desa terindah dunia versi majalah Travel Budget tahun 2016, menjadikannya sebagai daerah tujuan wisata. Namun dengan UKM batik Pariangan yang baru diresmiklan pada tahun 2017, para pengrajin masih menghasilkan produk yang terbatas dari segi bentuk dan desainnya. Hal inilah yang menjadi permasalahan dari pengrajin dikarenakan ketidakmampuan mereka dalam mengembangkan usaha tersebut karena keterbatasan pengetahuan. Banyak wisatawan yang datang ke Pariangan, namun mereka kembali tanpa membawa cendramata khas Pariangan yang nyatanya belum banyak dilirik oleh masyarakat disekitarnya. Oleh karena itu, dengan adanya kegiatan pelatihan ini, pengrajin batik Pariangan memiliki wawasan dan pengetahuan lebih untuk mengembangkan usaha batik tersebut. Dengan kegiatan pelatihan ini, para pengrajin diharapkan untuk bisa menghasilkan beragam produk dari kain batik yang ada. Kegiatan pelatihan batik ini dilaksanakan seiring dengan semakin meningkatnya permintaan dari wisatawan terhadap produk batik yang lebih variatif dan ramah di kantong. 
Pada kegiatan pelatihan ini pengrajin diberi materi pelatihan mengenai pemanfaatan kain perca batik menjadi produk yang bernilai jual tinggi. Produk produk yang dihasilkan seperti sandal dan sepatu batik, serta kotak tisu dengan motif batik. Produk yang dihasilkan dari kain perca batik ini akan dapat meningkatkan pendapatan dari pengrajin, dikarenakan tidak adanya kain batik yang terbuang percuma. Selanjutnya pengrajin juga diberi materi pelatihan pengembangan produk batik yang dihasilkan. Produk batik yang selama ini dibuat hanya berupa kain panjang dan baju kurung. Namun dengan kegiatan pelatihan ini, para pengrajin diberi materi mengenai bagaimana cara mengembangkan produk batik yang dihasilkan. Salah satu pengembangannya adalah dengan membuat sajadah batik dan syal batik. Pembuatan sajadah batik dan syal batik ini memanfaatkan kain batik yang dibuat menjadi kain panjang. Dengan membuat sajadah batik dan syal batik tersebut, maka wisatawan akan memiliki beragam pilihan souvenir batik dari Pariangan dan harganya juga lebih terjangkau. Dengan harga yang lebih terjangkau tersebut, tentunya juga akan meningkatkan penghasilan dari pengrajin yang ada.

Diakhir kata penulis mengucapkan terimakasih kepada Direktorat Riset dan Pengabdian Masyarakat (DRPM) Kemenristek DIKTI yang telah memberikan dukungannya melalui Program Kemitraan Masyarakat sehingga kegiatan ini dapat terlaksana dengan baik. Selanjutnya diharapkan agar kegiatan ini bisa menjadi rujukan bagi kegiatan lain yang sejenis untuk bisa meningkatkan potensi dan pemberdayaan masyarakat.

\section{DAFTAR PUSTAKA}

Antara, Batik Indonesia Resmi Diakui UNESCO, http/www.antaranews.com/berita/1254491066, diakses 5 Agustus 2018 (12.40).

Prahastutiningtyas, Yashinta dan R. Eka Rizkiantono. 2016. Perancangan Motif Batik Berkarakter Kediri. Jurnal Sains Dan Seni. Vol. 5, No.2, (2016) 2337-3520 (2301-928X Print), Institut Teknologi Sepuluh Nopember (ITS). Surabaya

Prawira, N. Ganda \& Dharsono. 2003. Pengantar Estetika dalam Desain Seni Rupa.Bandung : Departemen Pendidikan Nasional.

S, Endik. 1986. Seni Membatik. PT. Safir Alam: Jakarta.

Sachari, Agus danYan Yan Sunarya. 2000. Tinjauan Desain. Penerbit ITB. Bandung.

Salah, Wahab. 1992. Manajemen Kepariwisataan, Alih Bahasa Frans Gamong. Pradya Paramitha. Jakarta

Sastrayuda,S. Gumelar. 2010. Pengembangan Kawasan Desa Wisata. PT Gramedia Pustaka Utama. Jakarta.

Wulandari, Ari. 2011. Batik Nusantara Makna Filosofis Cara Pembuatan Dan Industri Batik. CV Andi Offset. Yogyakarta.

\section{Daftar Informan}

Irwan Malin Basa (Peneliti Batik Khas Pariangan) 